\title{
Gender Inclusive Curriculum in Higher Education
}

\author{
Lift Anis Ma'shumah ${ }^{1}$, M Rikza Chamami \\ Universitas Islam Negeri Walisongo Semarang-Indonesia ${ }^{1,2}$ \\ \{lift_anis@walisongo.ac.id ${ }^{1}$,rikza@walisongo.ac.id $\left.{ }^{2}\right\}$
}

\begin{abstract}
The discourse on gender is an interesting issue. Education has an important role in minimizing gender disparities. Internalization of gender-fair values can be carried out through designing a gender inclusive curriculum. This study aims to uncover how to designing gender inclusive curriculum in Higher Education. This research is a qualitative research with a survey method conducted in 16 universities in Indonesia. The samples were taken by using a random sampling technique. The data were obtained from questionnaires and interviews. To analyze, it used descriptive and gender analysis techniques. The result show, in the preparation of a gender inclusive curriculum in higher education, there are two design; (1) Integration model (use the Additive Approach through Hidden Curriculum); and (2) Separated model (use the Contributions Approach through Overt Curriculum). There are 3 factors that determine the implementation of a gender inclusive curriculum; (1) training on gender, lecturers' viewpoint on gender and culture.
\end{abstract}

Keywords: Curriculum; Gender Inclusive; Higher Education

\section{Introduction}

The spirit of discussion about gender both in the discourse and the realities of life is to achieve gender justice and equality. It is important because any discussion about gender differences and relations always raises what is called gender disparity or injustice. Gender differences would not become a problem as long as they do not create gender injustice. But what happens is the opposite, gender differences cause gender injustice. Mansour Fakih [1, p. 12] mentioned several kinds of gender injustice such as marginalization, subordination, labeling (stereotypes), violence, and double burden.

Law No. 12 of 2012 concerning Higher Education mandates that education must be undertaken with democratic principle, fair, and non-discriminatory. It implies that the campus/university must be a gender-friendly educational institution. The system of education has an important and central role in minimizing gender disparities or injustices that occur in society. Education is the key to realizing gender justice in society as it is not only a medium to transfer knowledge but also to transfers values or norms including gender-just values to society. Thus, one of the entry points is by designing a gender inclusive curriculum. The efforts for structurally gender mainstreaming can be conducted by reviewing curriculum and textbooks whether the curriculum has a gender perspective or not.

So far there have not been many formulas for gender-inclusive curriculum. Research conducted by Waryono [2, p. 7] shows that there are still many gender biases in textbooks, 
especially fiqh because the curriculum is not systematically designed and uses gender biased sources. Syafrida [3, p. 68] found gender bias not only in teaching material but also in images that strengthen the domestication of women. Elfi [4, p. 54] also found the same thing, gender roles have been constructed in segregation, where men's roles in the public sphere and women's roles in the domestic sphere.

These three research results above reinforce the need for a gender-inclusive curriculum design. Pateman [5, pp. 26-38]; [6] [7] urges a radical transformation in democratic theory, so a transformationin curriculum theory and formulation is needed, beyond "inclusive" approaches whichmerely seek to incorporate marginalised groups within a mainstream curriculum which fundamentally represents hegemonic world views.

This study aims to answer how to design a gender inclusive curriculum in Higher education in Indonesia. In addition to the trends in the widely used models, this study also looks at factors from the dynamics and design trends used in Higher Education. Gender insight and lecturer readiness are certainly determinants factor of the implementation of the genderinclusive curriculum, in the teaching and learning process.

\section{Method}

This research is a qualitative research with a survey method. According to Sugiyono [8, p. 8], qualitative research is a research method used to examine the conditions of natural objects. Natural objects are objects that develop as they are, not manipulated by researchers and the presence of researchers does not affect the dynamics of these objects.

The focus of this study is designing gender inclusive curriculum in Higher Education. This study conducted in 16 universities under Ministry of Religius Affair Republic of Indonesia. The samples were taken by using a random sampling technique. To collect the data, this study uses questionnaires and interviews method, and the technical analysis of the data uses descriptive analysis and gender analysis technique.

\section{Results}

In this section, the results of research on gender inclusive curriculum in Higer Education will be presented. The presentation of the research results is divided into two parts i.e. gender inclusive curriculum in Higher Education and factors. The results of research on gender inclusive curriculum design in tertiary institutions can be seen in the table below.

Tabel 1. Summary of Gender Inclusive Curriculum Design in Higher Education

\begin{tabular}{lcccc}
\hline & Yes & $\mathbf{\%}$ & No & \% \\
\hline $\begin{array}{l}\text { Training on gender inclusive curriculum } \\
\text { development }\end{array}$ & 6 & 37,5 & 10 & 62,5 \\
$\begin{array}{l}\text { Gender issues are included in the curriculum } \\
\text { explicitly }\end{array}$ & 4 & 25 & 12 & 75 \\
$\begin{array}{l}\text { Islam and gender subject } \\
\text { Integration of gender values in the course }\end{array}$ & 6 & 37,50 & 10 & 62,50 \\
\hline
\end{tabular}

The results of the study show, in the preparation of a gender-inclusive curriculum, most universities (11 Universities or 68,75\%) use integration model. Ideas about gender are included and linked to the existing curriculum, without changing the curriculum. This is done 
through the integration of gender into subjects, such as tafsir, fiqh, hadith. Meanwhile, in some universities (4 Universities or $75 \%$ ) gender issues have been explicitly included in the curriculum, even as a subject in 6 Universities. Based on these two models, the first model by means of integration is called the Hidden Curriculum model while the second model in an explicit way or a separate subject is called the Overt Curriculum model [9], [10, p. 243]. Training on gender inclusive curriculum is an important component in the development of a gender inclusive curriculum. The data show not all universities have implemented gender inclusive curriculum training. Only 6 universities $(37,5 \%)$ have conducted training on gender inclusive curriculum.

Tabel 2. Factors in Implementation of Gender Inclusive Curriculum

\begin{tabular}{lcc}
\hline Factors & $\mathbf{N}$ & $\mathbf{\%}$ \\
\hline Gender Training & 10 & 33,33333 \\
Lecturers' viewpoint on gender & 13 & 43,33333 \\
Culture & 7 & 23,33333 \\
\hline
\end{tabular}

There are 3 factors that determine the implementation of a gender inclusive curriculum; (1) the experience of lecturers in participating in training on gender inclusive curriculum development (10 lecturers or 33,33\%); (2) lecturers' viewpoint on gender (13 lecturers or $43,33 \%$ ) and (3) Culture (7 lecturers or $23,33 \%$ ).

\section{Discussion}

Gender mainstreaming in higher education cannot be separated from the curriculum and learning. According to Waryono [2, p. 7], efforts for structurally gender mainstreaming can be conducted by reviewing curriculum and textbooks whether the curriculum has a gender perspective or not. And then it also lies in the implementation of the learning.

The curriculum is a set of content, activities and experiences that will be carried out by students. Gender perspective curriculum is a curriculum that provides opportunities for all students without discrimination in gaining learning experiences as stated in the applicable curriculum. Gender perspective curriculum allows all students to develop their potential optimally without discrimination on gender.

There are three kinds of curriculum development [11, pp. 178-196]: Separate curriculum, the curriculum in which the subjects are designed to be given separately; Integrated curriculum, a curriculum whose teaching materials are given in an integrated manner and Correlated curriculum, a curriculum whose teaching materials are designed and presented in a correlation with other teaching materials.

The results of this research can be understood that the gender inclusive curriculum model in higher education mostly uses the integration model. This is implemented through a hidden curriculum [10, p. 243] with an Additive approach [12, p. 182]. The Additive approach it means without changing the existing curriculum, but adding variations on it. The new thoughts and ideas on gender can be included and linked to the existing curriculum. Strengthening the results of this study is a study by Yu'timaalahuyatazaka [13, p. 304], he said that to construct education with a gender sensitive paradigm, an integrated approach is needed. Islamic religious education subjects need to be integrated with the universal normative message of the Koran such as the values of equality, justice and equality. 
To integrating curriculum,[14] there are four approaches. These four approaches are hierarchical in nature, ranging from simple and superficial to complex and profound. The four level can be viewed, as follows:

Table 3. Level of Integrating Diversity into The Curriculum (Banks)

\begin{tabular}{ll}
\hline \multicolumn{1}{c}{ Level } & \multicolumn{1}{c}{ Approach } \\
\hline $\begin{array}{l}\text { level 1, the contributions approach } \\
\text { level 2, the additive approach }\end{array}$ & $\begin{array}{l}\text { focuses on heroes, holidays, and discretecultural elements } \\
\text { content, concepts, themes, and perspectivesare added to } \\
\text { the curriculum withoutchanging the structure of the curriculum } \\
\text { level 3, the transformation approach } \\
\text { structure of the curriculum is changed toenable students to view } \\
\text { concepts, issues, events, and themes from the perspectives } \\
\text { ofdiverse ethnic and cultural groups } \\
\text { level 4, the social action approach }\end{array}$ \\
& $\begin{array}{l}\text { students make decisions on importantsocial issues and take } \\
\text { actions to help solvethem }\end{array}$ \\
\hline
\end{tabular}

$[15$, p. 12]

Base on the table 3, integrated model in gender inclusive curriculum in higher education at level 2 with an additive approach. The new thoughts and ideas on gender can be included and linked to the existing curriculum, without changing the existing curriculum. This is due to several factors in integration model of gender inclusive curriculum, e.i; not many universities have conducted gender inclusive curriculum training, it does not change curriculum structure, does not increase the time allocation, the material developed in contextual and factual and the values of justice and gender equality can be integrated or formulated into indicators or learning activities. Gender equality and justice can be realized through four indicators i.e. access, participation, control, and benefits, or often referred to as APKM. Gender inclusive curriculum need modification of various curriculum components.

The integration model in the gender-inclusive curriculum above certainly has many problems, especially for lecturers. Understanding of gender and the experience of lecturers will greatly determine the successful implementation of this integration model. One of the factors that cause injustice or violence is the wrong understanding and interpretation of religion. One's understanding of the concept of gender itself also results in the emergence of unequal attitudes and behavior in society. The concept of gender must be understood as a concept to differentiate men and women from a socio-cultural perspective. Refer to Nasaruddin [16, p. 36] gender issues are related to the development of aspects of a person's masculinity or femininity and this is different from the term sex which refers to the development of biological aspects.

By understanding the concept of gender justice and equality, it would affect a person's attitudes and behavior in life. Someone will behave and act based on the principle of equality. On the other hand, people possibly act discriminatively if they do not understand this concept. Human behavior is the result of any kind of experiences and interactions between humans and the environment which are manifested in the form of knowledge, attitudes, and actions.

Therefore, to ensure that gender justice and equality can run optimally in gender-inclusive curriculum and learning, a lecturer must have equipped themselves with three things; sufficient viewpoint of gender justice and equality, gender sensitivity, and attitudes and actions against gender discrimination[17]. Gender insight of lecturer is the basic framework in making course syllabus and the learning process in gender perspective. Related to framework of 4Rs - redistribution, recognition, representation and reconciliation-for analysing gender justice in and through education, representative gender justice in education would require that 
both female and male education leaders, curriculum and textbook personnel and teachers have equity in education decision making.[18, p. 29]

Curriculum and learning are two interrelated elements. The curriculum is a set of content and activities that will be carried out by students, while learning describes how the interactions between students, lecturers, and teaching materials. Through this curriculum and learning, equality values can be transferred to students as well as absorbed and implemented in everyday life that describes daily thoughts, attitudes, and behaviors. In addition, for lectures, to enhance ones learning gender oriented should be given training on curriculum and learning design from a gender perspective.

Yet, the lecturers' viewpoint on gender justice and equality and training on gender are not the only factor that affects the way and attitudes of the lecturers in teaching. The other determining factor is the culture of the local community where they live. Women have been perceived as domestic people, whose space is very limited. Gender inequality that occurs is due to the strong view in society that man and women have different values. Cultural practices such as segregation and gender differences often prevent women from attending school.

In this case, we know that gender inclusive curriculum as a strategic plan. Elsewhere [5, p. 27], said: firstly, philosophically and pedagogically, "inclusive curriculum" is in fact a valuable, long-term educational objective, rather than being a strategy for affirmative action on behalf of those students whose needs it claims to address, and secondly, that "inclusive curriculum" has never been adequately distinguished from the "common" curriculum, which we know isutilised by boys and girls in quite different ways.

\section{Conclussion}

Based on the problems and research results as stated above, it can be concluded that not many universities have gender inclusive curriculum and include gender issues explicitly in the curriculum. Therefore, in gender inclusive curriculum, gender values have been integrated into the courses by lecturers in the teaching and learning process. They have given equal opportunities for both male and female students to actively participate in the learning process and have equal access to utilizing media and learning resources. This requires lecturers to have a good understanding of gender and a gender sensitive attitude in learning. A gender sensitive culture also needs to be realized in supporting gender equality and justice in education.

\section{References}

[1] Mansour Fakih, Analisis Gender dan Transformasi Sosial. Yogyakarta: Pustaka Pelajar, 1999.

[2] Isnanto and Waryono, Isu-Isu Gender dalam Kurikulum Pendidikan Dasar dan Menengah. Yogyakarta: IISEP, 2004.

[3] Syafrida, 'EVALUASI MATERI PENDIDIKAN ISLAM PERSPEKTIF GENDER (Evaluasi Terhadap Materi Buku Ajar Agama Islam)', Marwah J. Perempuan, Agama dan Jender, vol. 14, no. 1, p. 57, Jun. 2015, doi: 10.24014/marwah.v14i1.2594.

[4] E. Muawanah, Pendidikan Gender Dan Hak Asasi Manusia. Yogyakarta: Teras, 2009.

[5] V. Foster, 'Is "gender-inclusive" curriculum the answer for girls?', in Educating Girls Practice and Research, G. C. Leder and S. N. Sampson, Eds. Sidney: Allen \& Unwin, 1989. 
[6] L. Yates, 'A tale full of sound and fury--signifiying what? Feminism and curriulum policy in Australia', 1991.

[7] L. Yates, 'Gender inclusive curriculum', 1991.

[8] Sugiyono, Metode Penelitian Pendidikan Pendekatan Kuantitatif, Kualitatif, dan R\&D. Bandung: Alfabeta, 2016.

[9] S. R. Dzuhayatin, 'Gender and Pluralism in Indonesia', in The Politics of Multicultralism: Pluralism and Citizenship in Malaysia, Sinagpore, and Indonesia, R. W. Hefner, Ed. Honolulu: University of Hawai Press, 2001.

[10] A. Qibtiyah, Feminisme Muslim di Indonesia. Yogyakarta: Suara Muhammadiyah, 2019.

[11] S. Nasution, Asas-Asas Kurikulum. Jakarta: Bumi Aksara, 2003.

[12] Susilaningsih and A. M. Najib, Kesetaraan Gender di Perguruan Tinggi Islam. Yogyakarta: UIN Sunan Kalijaga dengan McGill IISEP, 2004.

[13] Y. Yatazaka, 'Gender dan Pengembangan Pemikiran Pendidikan Islam', J. Pendidik. Islam, vol. 3, no. 2, p. 289, Dec. 2014, doi: 10.14421/jpi.2014.32.289-306.

[14] J. A. Banks and C. A. Banks, Multicultural Education: Issues and Perspectives. Indianapolis: Allyn and Bacon, 1989.

[15] F. Savitz, 'Gender Equity and The Inclusive Calssroom', 1997.

[16] N. Umar, Argumen Kesetaraan Gende Perspektif Al Qur'an. Jakarta: Paramadina, 1999.

[17] M. A. Yakin, Pendidikan Multikultural, Cross-Cultural Understanding Demokrasi dan Keadilan. Yogyakarta: Pilar Media, 2007.

[18] N. Durrani and A. Halai, 'Dynamics of gender justice, conflict and social cohesion: Analysing educational reforms in Pakistan', Int. J. Educ. Dev., vol. 61, pp. 27-39, Jul. 2018, doi: 10.1016/j.ijedudev.2017.11.010. 